\title{
Blood profile of growing rabbits fed roasted solvent extracted castor seed meal
}

Ogunbode, A. A., Oladapo, O. S., Adeniyi, O. A. and Oyetola, A. M. Department of Animal Production Technology, Faculty of Animal and Fisheries Technology,

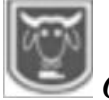

Abstract aaogunbode@gmail.com; +2348062455318

Sixteen growing rabbits with mean initial body weight of $750 \mathrm{~g}$ were used in a feeding trial that lasted 56 days. The animals were randomly allotted into four (4) dietary treatment groups consisting of four (4) animals per group. Each treatment groups was replicated twice with individually housed rabbit per replicate. The four dietary treatments contained 0, 0.5, 1.0 and $1.5 \%$ replacement levels of roasted-solvent extracted castor seedmeal (RSECSM) for soyabean in a completely randomized design experiment. The parameters investigated were haematological and serum indices. At the end of the feeding trial, blood samples were collected from the animals through the heart (left side) for haematology and serum indices. Eight (8) growing rabbits at the rate of two (2) animals per treatment were stunned and sacrificed for the blood collection. Data obtained were subjected to one way analysis of variance. The results show that feeding of RSECSM to growing rabbits did not show any significant $(p>0.05)$ effect on PCV, Hb and RBC while the inclusion of RSECSM at graded dietary level had significant $(p<0.05)$ effect on the WBC, WBC counts and Platelets. The WBC values ranged from 11025.00 - 14900.00 while the values for platelets ranged from 72500.00 - 30500.00 respectively. Among the leukocyte differential counts examined lymphocytes, monocyte and eosinophil were significantly $(p<0.05)$ different among the dietary treatments, however neutrophil was not significantly $(p>0.05)$ different among the means. The serum indices such as total protein, albumin, globulin, creatinine examined were not significantly ( $p$ $>0.05)$ affected by the dietary treatment except the cholesterol. The results of this study indicated that $1.5 \%$ inclusion levels of RSECSM in the growing rabbit diet affect some haematological parameters while it appears to be the optimum level for serum indices.

Keywords: Castor seed, growing rabbit, haematology, roasting, serum, solvent

\section{Introduction}

The need to provide sufficient animal protein for the growing human population is of great importance to animal scientist and developing livestock industry has been reported to be the best approach of bridging the protein deficiency being faced in the tropical countries (FAO, 2000). The protein intake in most developing countries is very low due to the high cost of production of the simple stomached animals that depend on conventional feedstuffs used as staple food by mankind. In order to have a fast means of protein supply, the rabbit production must be developed this is because of rabbit's high prolificacy, high genetic potential, better feed utilization, rapid growth rate and lack of taboos to rabbit production and consumption (Cheeke, 1980). Rabbit meat is a source of healthful food as it is low in cholesterol and sodium and high in protein (Aduku and Olukosi, 1990). Rabbits can also utilize the available proteins in cellulose rich plants where is not economical to feed these to poultry species. However, the high cost of feeds poses constraint to increase protein supply. It is due to the above reason that nutritionists are researching to discover new feeding materials to increased livestock production. Investigation on the alternative use of castor seeds in place of soyabean in this study is 


\section{Blood profile of growing rabbits fed roasted solvent extracted castor seed meal}

part of such efforts. Castor seed (Ricinus communis) is a novel legume and like all legumes may be an important source of plant protein. Preliminary works (Akande et al., 2011) reported that castor seeds contain ricin, ricinine and thermolabile allergen (Olsnes, 2004).Despite the presence of the numerous anti-nutrients, processing techniques involving traditional and mechanical are attempted in this study to improve the nutritive value of castor seeds and make it acceptable by the rabbits. This study therefore, evaluated the effect of roasted - solvent extracted castor seed as unorthodox feed ingredients on the haematological and serum indices of growing rabbit.

\section{Materials and methods Experimental site}

The experiment was carried out at the rabbit unit of the Teaching and Research Farm, Oyo State College of Agriculture and Technology, Igboora, Nigeria. The experimental areas lies in savannah forest zone on latitude $7^{0} 43 \mathrm{~N}$ and longitude $3^{\circ}$ $28 \mathrm{E}$ in an elevation of $140 \mathrm{~m}$ above sea level. The average minimum temperature is above $21.5^{\circ} \mathrm{C}$ and maximum average temperature is about $32.5^{\circ} \mathrm{C}$

Collection and preparation of the test ingredient

Ripened and matured castor seeds were purchased from castor grown farmers in Orire local government area of Oyo State, Nigeria. The seeds were removed of dirts, stones and roasted using an open pan place on burning fire wood supplying a steady flame. The seeds were constantly stirred with a spoon so as to have a uniform roast and prevent the seeds from burning. The roasting was done for 17 minutes at $20^{\circ} \mathrm{C}$ and the oil was extracted using solvent extractors. The meal produced was used to formulate four isocaloric and isonitrogenous diets.

\section{Experimental diets}

Four (4) experimental diets were compounded arising from the replacement of soyabean with $0 \%, 0.5 \%, 1.0 \%$ and $1.5 \%$ roasted - solvent extracted castor seed meal. The substitution was nutrient for nutrient. The gross composition of the diets and determined analysis are presented in Table 1 . Management of the experimental animals A total of sixteen (16) crossbred growing rabbits (New Zealand White x Chinchilla) of mixed sexes weighing an average of $750 \mathrm{~g}$ were used for the experiment. The rabbits were purchased from a reputable rabbit farm from Osogbo in Osun State, Nigeria. The animals were randomly assigned into four treatments with four replicates each balanced for the group average weights. Prior to the arrival of the rabbits, the house and hutches were thoroughly washed, cleaned and disinfected. The experimental animals were housed in hutch equipped with individual feeding and drinking facilities. The hutches were raised from the floor and provided with wire screen floor to allow faeces and urine to drop to the cemented floor. Anti - stress was administered on the first two days of arrival followed by dewormer (albendazole). Ivomec was also given to eliminate ectoparasites in the second weeks of the experiment. The rabbits were fed ad libitum with the experimental diet and water was provided free choice

\section{Blood collection and evaluation}

At the end of eight weeks, prior to feeding in the morning, $5 \mathrm{ml}$ of blood was sampled from two rabbits per treatment through the heart (left side) of each animal using sterile disposable syringes and needles. The blood samples for haematological parameters were placed in sample bottles containing heparin. The haematological parameters assessed include Packed Cell Volume (PCV), Haemoglobin (Hb), Red Blood Cell (RBC), 


\section{Ogunbode, Oladapo, Adeniyi and Oyetola}

White Blood Cell (WBC), Platelets and leukocytes differential ( lymphocyte, neutrophil, monocyte and eosinophil). The packed cell volume (PVC) was determined using microhaematocrit method, while the haemoglobin concentration was determined by the cyanmethaemoglobin method. Red blood cells (RBC) and white blood cells (WBC) were counted using haemocytometer as outlined in Ewuola and Egbunike (2008). Blood samples were stained with Giemsa stain for differential leukocyte counts. The blood samples for serum indices evaluation were placed in collecting bottles containing no anticoagulant. The blood was allowed to clot and the serum was separated immediately by centrifugation at 3500rpm for 10 minutes. The serum indices determined include: total protein, albumin, globulin, cholesterol and creatinine. The serum indices parameters were assessed using spectrophotometric method.

\section{Data analysis}

All data obtained were subjected to analysis of variance (SAS, 2003) and means was separated using Duncan's Multiple Range test of the same software.

\section{Results and discussion}

The haematological parameters of crossbred growing rabbits fed graded levels of roasted - solvent extracted castor seed are presented in Table 2.There were no significant $(p>0.05)$ differences between the treatment groups for packed cell volume, haemoglobin and red blood cell . The packed cell volume, haemoglobin and red blood cell values were between (36.00 $40.00 \%),(11.95-13.55 \mathrm{~g} / \mathrm{dl})$ and $(5.84-$ $6.66 \times 10 \%$ ul) respectively. The haematological components measured were within the normal physiological ranges reported for rabbits : packed cell volume $(30-50 \%)$, haemoglobin (10.00 -
$15.00 \mathrm{~g} / \mathrm{dl}),(\mathrm{RAR}, 2009)$ and red blood cell $\left(4.00-8.60 \times 10^{6} / \mathrm{ul}\right)$ (Mitruka and Rawnsley, 1977). The non significant effects of dietary treatments on these parameters may suggest that the control diet and those formulated on graded levels of roasted solvent extracted castor seed meal were similarly acceptable and utilized by these animals. The higher values of packed cell volume and haemoglobin observed in the study are an indication that the animals did not manifest any anaemic condition and this also tends to indicate a better utilization of roasted - solvent extracted castor seed by the rabbit. Increased packed cell volume shows a better transportation and thus results in an increased primary and secondary polycythemia (Isaac et al., 2013). Haemoglobin has the physiological function of transporting oxygen to tissues of the animal for oxidation of ingested food so as to release energy for the other body functions as well as transport carbon dioxide out of the body of animals (Soetan et al., 2013). Isaac et al., (2013) opined that red blood cell is involved in the transport of oxygen and carbon dioxide in the body and a reduced red blood cell implies a reduction in the level of oxygen that would be carried to the lungs. However, a highly significant differences ( $p$ $<0.05$ ) existed among treatments in white blood cell, white blood cell differential counts and platelets. The major functions of the white blood cell and its differential are to fight infections, defend the body by phagocytes against invasion by foreign organism. The lower values of the WBC observed may be attributed to the effect of anti-nutritional factors (ricin) present in the test ingredient used in formulating the diets. Animals with low white blood cells are exposed to high risk of disease infection, while those with high counts are capable of generating antibodies in the process of phagocytosis and have high degree of 


\section{Blood profile of growing rabbits fed roasted solvent extracted castor seed meal}

resistance to diseases (Soetan et al., 2013).Platelets had significant effect ( $\mathrm{p}<$ 0.05 ) on the animal fed the roasted - solvent extracted castor seed meal. Blood platelets are implicated in blood clotting, low platelet concentration as obtained in rabbit fed processed castor seed meal suggested that the process of clot formation (blood clotting) will be prolonged resulting in excessive loss of blood in the case of injury (Nsa Abasi et al., 2014).The lower values obtain for lymphocytes, monocyte and eosinophil than the control value is an indication that the rabbits immune system was not challenged by toxic substance present in test ingredient. The higher values of neutrophil observed in the rabbits fed processed diets may suggest the resistance of the rabbits to disease conditions (Fouad and Bynner, 2008). Table 3 shows the serum metabolites of growing rabbits fed graded levels of roasted - solvent extracted castor seedmeal based diets. There were no significant ( $p>0.05$ ) effects in all the parameters except the cholesterol. The serum protein variables of animals fed test ingredients compared favourably with the control indicating that treatment with test ingredient possessed the same dietary qualities with the control diet. The results of the serum proteins imply that animals on the test ingredient utilized and synthesized the dietary protein from RSECSM adequately with the control group fed convectional soyabean meal. Albumin utilization and synthesis was enhanced in rabbits fed 0.5 and $1.5 \%$ RSECSM probably because of the increase in the level of crude protein available from the test ingredient at higher inclusion level in the diet, since albumin synthesis has been reported to be related to the amount of available protein (Iyayi and Tewe, 1998) in the diet. Serum albumin will increase when protein intake exceeds the amount required for maintenance and growth compared with the control diet (Ogunbode et al., 2016). Serum albumin is a strong predictor of health, a low albumin concentration is a sign of poor health (Kastow, 2009). The globulin values (g/dl) were 4.85 (0\% RSECSM), 4.90 (0.5\% RSECSM), 4.60 (1.0\% RSECSM) and 4.90 (1.5\% RSECSM).Compared with the control diet $(4.85 \mathrm{~g} / \mathrm{dl})$, the level of globulin was increased in rabbits fed diet containing processed castor seedmeal ( $\mathrm{p}$ $<0.05)$. Babatunde and Oluyemi (2000) opined that the higher the value of serum globulin, the better the ability to fight against diseases, hence rabbits on the treated castor based diets has the highest ability to combat the body disease compared with the control. Serum creatinine increased significantly as the dietary inclusion of RSECSM increased. Excess creatinine in the blood is from muscle when wasting occurs and creatinine phosphate is catabolized (Yuegang et al., 2008).This indicated that the rabbits were using body reserves to survive. The decrease in blood cholesterol in rabbit fed processed 0.5 and $1.0 \%$ of RSECSM could be attributed to the effects of ricin in castor seeds which significantly reduced blood cholesterol ( Mirhadi et al., 1992). However the highest cholesterol content found at $1.5 \%$ inclusion could be due to decrease in hepatic production of very low density lipoprotein which serves as the precursor of low density lipoprotein in the blood circulation ( Kim et al., 2008) 
Ogunbode, Oladapo, Adeniyi and Oyetola

Table 1: Effect of roasted-solvent extracted castor seed meal on haematological parameters of growing rabbit

\begin{tabular}{|c|c|c|c|c|c|}
\hline Parameters & T1 (0\%) & T2 (0.5\%) & T3 (1.0\%) & T4 (1.5\%) & SEM \\
\hline $\begin{array}{l}\text { Packed cell } \\
\text { Volume }(\%)\end{array}$ & 38.00 & 36.00 & 39.50 & 40.00 & 1.362 \\
\hline $\begin{array}{l}\text { Haemoglobin } \\
(\mathrm{g} / \mathrm{dl})\end{array}$ & 13.00 & 11.95 & 13.30 & 13.55 & 0.497 \\
\hline $\begin{array}{l}\text { Red blood } \\
\text { Cell }\left(10^{6} \mathrm{ul}\right)\end{array}$ & $6.32^{c}$ & $5.84^{\mathrm{d}}$ & $6.66^{\mathrm{a}}$ & $6.37^{\mathrm{b}}$ & 0.284 \\
\hline $\begin{array}{l}\text { White blood } \\
\text { cell }\left(10^{3} \mathrm{dl}\right)\end{array}$ & $14900.00^{\mathrm{d}}$ & $11025.00^{c}$ & $12100.00^{\mathrm{b}}$ & $142100.00^{\mathrm{a}}$ & 976.484 \\
\hline Lymphocyte (\%) & $56.50^{c}$ & $59.00^{\mathrm{a}}$ & $45.00^{\mathrm{d}}$ & $52.00^{c}$ & 2.256 \\
\hline Monocyte (\%) & 2.50 & 2.00 & 2.00 & 2.50 & 0.313 \\
\hline Eosinophil (\%) & $3.50^{\mathrm{a}}$ & $2.50^{\mathrm{b}}$ & $1.50^{\mathrm{cd}}$ & $2.00^{c}$ & 0.324 \\
\hline Nuetrophil (\%) & $37.50^{c}$ & $36.50^{\mathrm{cd}}$ & $51.56^{\mathrm{a}}$ & $43.50^{\mathrm{b}}$ & 2.448 \\
\hline Platelet $\left(10^{3} / \mathrm{ul}\right)$ & $144,000.00^{\mathrm{b}}$ & $72500.00^{\mathrm{d}}$ & $305000.00^{\mathrm{a}}$ & $112500.00^{c}$ & 37094.474 \\
\hline
\end{tabular}

Table 2: Effect of roasted-solvent extracted castor seed meal on the serum metabolites of growing rabbits

\begin{tabular}{llllll}
\hline Parameters & T1 $(\mathbf{0 \%})$ & T2 $(\mathbf{0 . 5 \%})$ & T3 $(\mathbf{0 . 5 \%})$ & T4 $(\mathbf{1 . 5 \% )}$ & SEM \\
\hline Total protein $(\mathrm{g} / \mathrm{dl})$ & $8.35^{\mathrm{c}}$ & $8.55^{\mathrm{b}}$ & $7.65^{\mathrm{d}}$ & $8.70^{\mathrm{a}}$ & 0.165 \\
Albumin $(\mathrm{g} / \mathrm{dl})$ & $3.50^{\mathrm{c}}$ & $3.60^{\mathrm{b}}$ & $3.05^{\mathrm{d}}$ & $3.80^{\mathrm{a}}$ & 0.113 \\
Globulin $(\mathrm{g} / \mathrm{dl})$ & $4.85^{\mathrm{b}}$ & $4.90^{\mathrm{a}}$ & $4.60^{\mathrm{c}}$ & $4.90^{\mathrm{a}}$ & 0.059 \\
Creatinine $(\mathrm{mg} / \mathrm{dl})$ & $1.15^{\mathrm{c}}$ & $1.30^{\mathrm{b}}$ & $0.90^{\mathrm{d}}$ & $1.40^{\mathrm{a}}$ & 0.083 \\
Cholesterol $(\mathrm{mg} / \mathrm{dl})$ & $31.00^{\mathrm{b}}$ & $29.00^{\mathrm{c}}$ & $27.00^{\mathrm{d}}$ & $47.50^{\mathrm{a}}$ & 3.128 \\
\hline a,b,c,d, means on the same row with different superscript differ significantly $(\mathbf{p}<\mathbf{0 . 0 0 5})$ &
\end{tabular}

\section{Conclusion}

Roasted solvent extracted castor seed meal impact negatively on the haematological parameters of growing rabbits however, the test ingredient did not have any adverse effect on the serum indices of the animal. It can be concluded that feeding growing rabbit with processed castor seed meal above $1.5 \%$ will significantly alter the haematological and serum indices and probably induce anaemic conditions in the animals.

\section{References}

Aduku, A. O. and Olukosi, J. O. 1990. Rabbit management in the tropics, Books gospel publication, Abuja.pp 40.
Akande, T. O., Odunsi, A. A. and Adedeji, O. S. 2011. Toxicity and nutritive assessment of castor (Ricinus communus) oil and processed cake in rat diet. Asian J. Anim .Sci 5. Pp $330-339$.

Babatunde, B. B. and Oluyemi, J.A. 2000. Comparative digestibility of three commonly used fibrous ingredients in maize - soyabean fish diet by broiler chicks. Trop. J. Anim. Sci. 3 :p $105-111$.

Cheeke, P.R. 1980. The potential role of the rabbit in meeting world food needs. J. Appl. Rabbit Research 3 (3):3-5.

Ewuola, E. O. and Egbunike, G. N. 2008. Haematological and serum biochemical response of growing 
Blood profile of growing rabbits fed roasted solvent extracted castor seed meal

rabbit bucks fed dietary fumonisin B1. Afr. J. Biotechnol, 7 : 4304 4309

FAO, 2000. Food and Agriculture Organization of the United Nations, Rome, Quarterly Bulletin of Statistics 1:30-32

Fouad, N. A. and Bynner, E. 2008. Work transitions. American psychologist 63(4): $241-244$

Isaac, L. J., Abah, G., Akpan, B. and Ek a e t t e, I . U . 2013 . Haematological properties of different breeds and sexes of rabbits. Proceedings of the $18^{\text {th }}$ annual conference of animal science association of Nigeria. Pp. 24-27

Iyayi, E. and Tewe, O. O. 1998. Serum total protein, urea and creatinine levels as indices of quality of cassava diets for pigs. Trop. Vet., 16 :59-67

Kastow.com. 2009. Globulin, total proteins. Available at http//www.drkastow.com/htm/prot ein.albumin.globulin.htm

Kim, H. Y., Shin, H. S., Park, H., Kim, Y. C., Yun, Y. G., Park, S., Shin, H. J. and Kim, K. 2008. In vitro inhibition of coronavirus replications by the traditionally used medicinal herbal extracts. Gimicifuga rhizoma, Meliae cortex, Coptids rhizoma and Phellodendran cortex. Journal of clinical virology, 41: $122-128$

Mitruka, B. M. and Rawnsley, H. M. 1977. Clinical biochemical and haematological reference value in normal experimental animals. Masson publication, New York, USA., ISBN 13:9780893520069, PP: $21-64$

Mirhadi, S. A., Singh, S. and Gupta, P. P.
1992. Effect of garlic supplementation to cholesterol rich diet on development of atherosclerosis in rabbits. Industrial Journal of Experimental Biology. 29: $162-168$.

NseAbasi, N. E., Williams, M. E., Akpabio, and Edem, E. A. Offiong, 2014. Haematological parameters and factors affecting their values. Agricultural science volume 2. Issue $1: 37-47$

Ogunbode, A. A., Okeniyi, G., Fatola, O. S. G., Ogunjimi, B. A. and Folarin, M. O. 2016. Haematology and serum indices of weaner pigs fed raw pride of Barbados (Caesalpina pulcherrima) seed meal. Nigerian J. Anim. Sci. (2) : 408-416

Olsnes, S. 2004. The history of ricin, abrin and related toxin. Biochem. 44. Pp : $361-370$

Research Animal Resource (RAR). 2009. Reference value for laboratory animals: Normal haematological values. RAR Websites, RAR, University of Minnesota. Retrieved

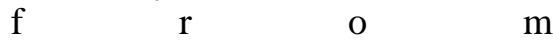
http://www.ahc.umm.edu/rar/refval ues.html.

SAS, 2003. SAS/STAT User's guide : version 8 for windows. SAS Institute Inc, Cary, NC., USA.

Soetan, K. O., Akinrinde, A. S. and Ajibade, T. O. 2013. Preliminary studies on the haematological parameters of cockerels fed raw and processed guinea corn ( Sorghum bicolour). Proceeding of the $38^{\text {th }}$ annual conf. of the Nigerian society for animal production. Pp. 49-52

Yuegang, Z., Chengjum, W. and Chengjum, T. 2008. Simultaneous 
Ogunbode, Oladapo, Adeniyi and Oyetola

determination of creatinine and uric acid in human urine by high performance li quid chromatography. Analytic science. $24: 1589-1592$

Received: $10^{\text {th }}$ July, 2017

Accepted: $9^{\text {th }}$ December, 2017 